\title{
消化器外科における術後感染症とその予防対策
}

\author{
東京医科米科大学第 2 外科 \\ 井上 敏直 宇都宮譲二 浅野 献一 \\ 同 微生物学教室 \\ 中 谷 林太 郎
}

\section{POSTOPERATIVE INFECTIOUS COMPLICATION IN GASTROINTESTINAL SURGERY AND ITS MANAGEMENT}

\section{Toshinao INOUE*, Jyoji UTSUNOMIYA*, Kenichi ASANO* and Rintaro NAKAYA**}

*Second Department of Surgery, ${ }^{* *}$ Department of Microbiology, Tokyo Medical and Dental University, School of Medicine

\begin{abstract}
衍後感染の発症には, 細菌性因子, 個体の感染防禦因子, 異物・手術手技等の因子が複雑に絡み合って おり, その予防のためには各々の要因に対し, 細心の注意をはらった対策が必要である. 消化器外科手術 に扣ける術後感染症の起炎菌の多くは，消化管内に常在する細菌であり，術後感染の予防と治療にあたっ ては, 手術対象とする臟器の常在細菌讘の実態と, 術後感染に拊ける起炎菌の各臟器別の検出状況, 薬剤 感受性傾向の現況を十分に把握することが重要である.
\end{abstract}

索引用語 : 術後感染症, 晹内細菌丵, 大腸手術前腸管処置法, 術中晹管洗浄法, 嫌気性菌

\section{I はじめに}

術後感染症の発症には, 局所に抢ける細菌の增加, 異 物の存在，宿主の 感染抵抗性減弱などの 要因が 考兄ら れ，その予防には，おの叔のの要因に対する対策が必要 である. 消化器外科手術後の感染症では, 消化管内常在 細菌の関与が最も特徴的であり, 術後感染の予防々治療 のためには, 腸内細菌叢の実態と術後感染に打ける起炎 菌, 薬剤感受性, 臓器別の特徴を十分に把握する必要が ある. 近年, 嫌気性菌の検出・同定法を中心とした細菌 学のめざましい進歩により, 腸内細菌叢の実態(1) ${ }^{(2)}$ や感 染症に括㚈る嫌気性菌の関与年 ${ }^{3)}$ 等が次第に明らかにさ れつつある.私どもは，この最新の腸内細菌叢検出の手 技占を用い，消化器外科手術後の感染症の現況とその予 防対策を，とくに，術後感染に淤ける嫌気性菌の関与と 大腸手術時の腸管処置法の面から検討を加えた。

* 第15回日消外会総会シンポ 1 消化器外科と感染

\section{II 術後感染症の現況}

\section{1. 術後感染の種類と頻度}

教室に括ける1971年から1979年むでの 9 年間の外科手 術2,819例の術後感染症は298例で, 術後感染症の発生頻 度は全手術例の $10.6 \%$ であった。無菌手術では $1.7 \%$, 準無菌手術では, 食道・胃・十二指腸手術の $16.7 \%$, 下 部消化管手術の $29.2 \%$, 肝胆膵手術の $11.9 \%$, 虫垂切除 や腸管切除を伴わないその他の腹腔内手術の $4.3 \%$ であ り，準無菌手術例の術後感染率は平均 $15.9 \%$ であった。 胃腸管の穿孔等の污染手術では $38 \%$ であり, 術後感染症 は，下部消化管および污染手術後に高率に発生した（表 $1)$.

消化器外科に括ける術後感染症の種類では, 創感染が $38.5 \%$ 之一番多く, 次いで腹腔内感染 $30.2 \%$, 呼吸器感 染 $13.1 \%$ ，尿路感染 $8.7 \%$ ，胆道感染 $3.3 \%$ ，敗血症 4.4 $\%$ ，その他1.8\%の順であった。

\section{2. 術後感染起炎菌の模出率}

過去 3 年間の消化器外科手術後の創感染と腹腔内感染 
表 1 手術後感染症の頻度（1971～1979年，手術総 数2819例)

\begin{tabular}{|c|c|c|c|}
\hline & 手術数 & 感染症数 & $\%$ \\
\hline 無菌手術 & 1145 & 20 & 1.7 \\
\hline 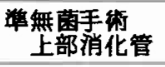 & 719 & 120 & 16.7 \\
\hline 下部消化管 & 295 & 86 & 29.2 \\
\hline 肝, 胆, 滕 & 354 & 42 & 11.9 \\
\hline そ の 他 & 256 & 11 & 4.3 \\
\hline \multirow[t]{2}{*}{ 后染手術 } & 50 & 19 & 38.0 \\
\hline & 2819 & 298 & 10.6 \\
\hline
\end{tabular}

の起炎菌をみると，検出率は Klebsiella $20.9 \% ，$ E. coli $17.4 \%$, Pseunomonas $12 \%$, Proteus $4.5 \%$, Enterbacter $3.5 \%$ ，Citrobacter 3.3\%であり，好気性グラム陰性桿菌 が70.5\%を占めており，グラム陽性球菌は $14.5 \%$ ，嫌気 性菌は10.9\%であった。手術対象の喴器別では，下部消 化管手術後の感染起炎菌におい, の検出率が高かった（表 2 ）.

\section{3. 術後感染起炎菌の薬剂感受性}

次に過去 3 年間の術後感染起炎菌の各種抗生阂に対す る感受性率をみると，Klebsiella に対しては広域合成ぺ ニシリンは無効であったが，その他の抗生剤には高度感 受性を示した．E. coli は比較的各種の抗生剤に感受性 を示したが, 耐性菌の出現もかなりみられた.

Pseudomonas aeruginosa B (PL-B), Colistin (CL), Sulbenicillin (SBPC), Carb-
表 3 術後感染分離菌の各種抗生剤に対する感 受性率 $(\%)$

\begin{tabular}{|c|c|c|c|c|c|c|c|c|c|c|c|c|c|}
\hline & 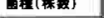 & TC & $C P$ & $S M$ & KM & GM & PL & CER & ABPC & CBPC & SBPC & $\mathrm{NA}$ & CL \\
\hline \multirow{3}{*}{17} & 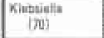 & 90 & 94 & 76 & 93. & 96 & 98 & 91 & 7 & 7 & 11 & 89 & 100 \\
\hline & $\begin{array}{r}\text { E. coli } \\
\text { (70) }\end{array}$ & 66 & 76 & 71 & 77 & 94 & 100 & 93 & 64 & 66 & 69 & 96 & 100 \\
\hline & $\begin{array}{l}\text { Pseudomonas } \\
\text { zer. (15) }\end{array}$ & 2 & 2 & 54 & 2 & 86 & 100 & 2 & 0 & 71 & 86 & 2 & 100 \\
\hline$\pi$ & \begin{tabular}{|} 
Enterobacter \\
(38)
\end{tabular} & 74 & 87 & 79 & \multicolumn{3}{|c|}{$95: 391 " z=87$} & 5 & 5 & 82 & 79 & \multicolumn{2}{|c|}{97 约 92} \\
\hline 1 & $\begin{array}{c}\text { Serratia } \\
(18)\end{array}$ & 11 & 56 & 28 & 72 & 78 & 17 & 6 & 11 & 33 & 28 & 89 & 6 \\
\hline \multirow[t]{3}{*}{ t } & $\begin{array}{c}\text { Froteus vid } \\
\text { (17) }\end{array}$ & 71 & 94 & $\bar{y} \dot{4}$ & 100 & 100 & 6 & 6 & 6 & 76 & 76 & 88 & 0 \\
\hline & $\begin{array}{l}\text { Proteus. miri. } \\
\text { (12) }\end{array}$ & 0 & 75 & 67 & 92 & 92 & 17 & \multicolumn{3}{|c|}{$100 \mathrm{z}=83$ 榇 83} & 80 & 100 & 0 \\
\hline & $\begin{array}{l}\text { in. Steptococcus } \\
\text { (22) }\end{array}$ & 77 & 95 & 59 & 41 & 86 & 5 & 100 & 95 & 100 & & & \\
\hline 4 & $\mid \begin{array}{c}\text { Aacuartidus } \\
\text { (ili) }\end{array}$ & 46 & 83 & 7 & 5 & 9 & 2 & 22 & 20 & 46 & 41 & 0 & 7 \\
\hline
\end{tabular}

enicillin (CBPC) に対して高い感受性を示した。 Serratia はアミノグリコシッド剤と Nalidixic acid (NA) にのみ高い感受性を示しただけで多くの抗生剤洏性を 示した。嫌気性菌の Bacteroides は，検索した12種の薬 剤の中では Chloramphenicol (CP) にの及高い感受性 を示し Tetracycline (TC), CBPC, SBPC に対しては 40\%台の感受性率であり，アミノグリュシッド剤には耐

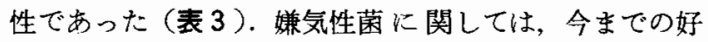
気性菌を主体とした培養法および感受性検査では治療の ための抗生剤選択の参考とならなかった。

\section{4. 術後感染症における嫌気性菌}

近年, 嫌気性菌の分離・同定法の進歩により, 感染症 に打ける嫌気性菌の関与が注目されてきているが，嫌気 性菌が常在細菌として存在する消化管を手術対象とする

表 2 消化器外科手術後の感染起炎菌（1977～1979）

\begin{tabular}{l|c|c|c|c}
\hline \multicolumn{1}{c|}{ 菌 属 } & 上部消化管 & 下部消化管 & 肝. 胆, 膵 & 合 計 \\
\hline $\begin{array}{c}\text { Aerobes } \\
\text { Klebsiella }\end{array}$ & 20.9 & 19.7 & 23.2 & 20.9 \\
\hline E. coli & 13.6 & 22.8 & 16.9 & 17.4 \\
\hline Pseudomonas & 13.4 & 8.5 & 14.2 & 12.0 \\
\hline Proteus & 4.0 & 7.7 & 1.4 & 4.5 \\
\hline Enterobacter & 3.4 & 2.3 & 5.6 & 3.5 \\
\hline Citrobacter & 3.1 & 1.1 & 7.7 & 3.3 \\
\hline その他のGNR & 9.1 & 6.6 & 12.7 & 8.9 \\
\hline Candida & 5.1 & 4.2 & 1.4 & 4.1 \\
\hline GPC & 17.1 & 12.0 & 12.7 & 14.5 \\
\hline Anaerobes & 10.3 & 15.1 & 4.2 & 10.9 \\
\hline & $100.0 \%$ & $100.0 \%$ & $100.0 \%$ & $100.0 \%$ \\
\hline
\end{tabular}


消化器外科においては, 術後感染に関与する嫌気性菌の 検出率および薬剤感受性についての現況を知ることが術 後感染の予防・治療に必要である.

そこで, 最近の教室に和ける消化器外科術後感染症 例より採取した膿50検体について，好気性菌・嫌気性 菌の検出状況を調べた。 50検体中, 培養陽性は 41 検体 であり，そのうちで嫌気性菌だけが検出されたのは 4 検体 $(9.8 \%)$, 好気性菌之嫌気性菌の混合感染は 22 検体 (53.6\%)，好気性菌だけが検出されたのは15例（36.6 $\%$ ）で培養陽性例の $63.4 \%$ の検体飞嫌気性菌が関与して いた，好気性菌検出を主体とした中検細菌部に甡ける過

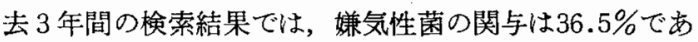
り，嫌気性菌に目をむけた細菌検查の必要性をらかがわ せた（表 4 ）。

表 4 Summary of the bacterial isolates obtained from 50 specimens (pus)

\begin{tabular}{l|c|c}
\hline \multicolumn{1}{c|}{ Specimens } & No. & \multicolumn{1}{c}{$\%$} \\
\hline \multicolumn{1}{c|}{ Total } & 50 & - \\
\hline Positive & 41 & 100.0 \\
\hline Positive for aerobes & 37 & 90.2 \\
\hline Positive for anaerobes & 26 & $\underline{63.4(36.5)}$ \\
\hline Mixed aerobes-anaerobes & 22 & 53.6 \\
\hline Aerobes only & 15 & 36.6 \\
\hline Anaerobes only & 4 & 9.8 \\
\hline Negative & 9 & - \\
\hline \multicolumn{2}{l|}{}
\end{tabular}

分離された菌種を検討すると，好気性菌はさきに述へ た過去 3 年間の検出率状況と著しい差は認められなかっ た. 嫌気性菌では, Bacteroides, Peptostreptococcus, Bifidobacterium, Eubacterium が高頻度に検出された。 中でも Bacteroides は60株中 29 株 $(48 \%)$ を占め最も検出率が 高かった（表5）.

嫌気性伛ついて, Minocycline (MINO), Oleandomycin (OM), Lincomycin (ICM), Clindamycin (CLDM), Metronidazole (MET), Ampicillin (ABPC), Cephalothin (CET) の 7 薬剤に対する最小発育阻止濃度 (MIC) を調べた. MINO は嫌気性菌全体に良い抗菌性を示 ᄂ, OM，LCM，CLDM は Bacteroides 以外の嫌気性菌 に良い抗菌性を示したが，Bacteroides の約半数に耐性株 を認めた. MET は Peptostrepococcus 以外の嫌気性菌に 対して低濃度で抗菌力を示した。Bacteroides は ABPC,
表 5 術後感染症例より分離された嫌気性菌

\begin{tabular}{l|r|r}
\hline \multicolumn{1}{c|}{ Organisms } & No. & $\%$ \\
\hline Bacteroides fragilis & 20 & 33 \\
\hline B.f lagilis以外の Bacteroides & 9 & 15 \\
\hline Peptostreptococcus & 6 & 10 \\
\hline Bifidobacterium & 4 & 7 \\
\hline Clostridium innocuum & 3 & 5 \\
\hline Megasphara elsdenii & 3 & 5 \\
\hline Fusobacterium & 3 & 5 \\
\hline Eubacterium & 4 & 7 \\
\hline Ruminococcus & 2 & 3 \\
\hline G (+) rod. & 2 & 3 \\
\hline G $(-)$ rod. & 4 & 7 \\
\hline \multicolumn{1}{c|}{ Total } & 60 & 100 \\
\hline
\end{tabular}

図 1 Bacferoides sp. の各種抗生㶡に対する MIC (25株)

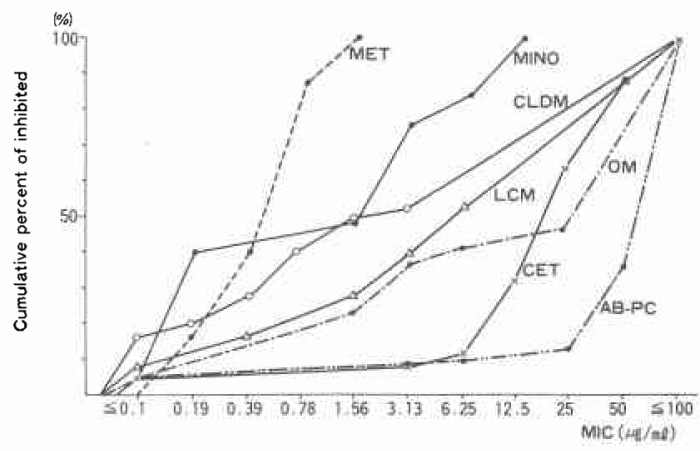

CETに対しては耐性株が多く, MET, MINO には良 い感受性を示したが，嫌気性菌に抗菌力のあるとされて いる CLDM, LCM に対しては，Bacteroides の約半数 が酎性を示したことは，最近報告されている CLDM に対する耐性菌の出現 ${ }^{6)}$ の問題として今後検討を加える ベき問題である(図1).

術後感染症において，近年嫌気性菌の検出される頻度 が増加してさた。このことは, opportunistic infection? としての嫌気性菌感染症が增加してきたことも1つの要 因であるが，嫌気性菌の分離・同定法の進歩によるとこ ろが大きい，術後感染症の治療，予防にあたっては，好 気性菌だけを目安に薬昘の選択をするのではなく，今後 は，嫌気性菌の存在を考慮した薬剤選択が必要となって くるものと思われる. 以上, 消化器外科術後感染の現況 
について述べてきたが，この現況を十分に把握した上 で，次に術後感染の予防対策について検討を加えた。

\section{III 衍後感染の予防対策}

\section{1. 消化管各部位の渴内細菌粦}

手術対象とする腸管における常在細菌，すなわち，感 染源の特徽を把握することは, 術後感染に関与する細菌 の種類が限定され, 術後感染の予防, 治療に有力な手助 けとなる。そこで，成人に批ける消化管各部位の常在細 菌叢を 42 症例の腸内容，排泄物の好気・嫌気両培養成績 から検討した（図2）.

\section{图 2 成人に怙ける消化管各部位の細菌丵}

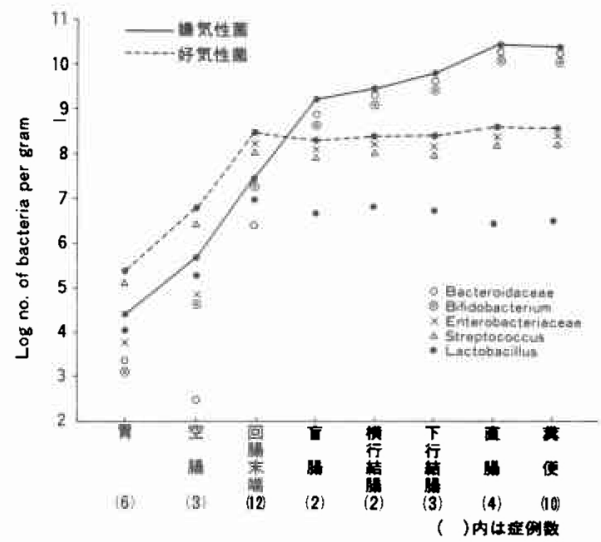

胃内に信ける細菌数および種類は，胃液酸度に影響さ れ，高酸の胃液では 細菌が 険出されない症例むあった が，平均 $1 \mathrm{mI}$ あたり $10^{5}$ 個の好気性菌と $10^{4}$ 個の嫌気性菌 が検出された. 菌の種類では, 好気性では Streptococcus. Lactobacillus, Enterobacteriaceae, 嫌気性では Bifidobacterium, Bacteroidaceae が多く検出された。 空腸より回腸に 行くにしたがって, 好気性菌, 嫌気性菌数は增加し, 回腸末端では好気性菌は $10^{8} / \mathrm{ml}$ ，嫌気性菌数は $10^{7} / \mathrm{ml}$ で あった．回盲弁を境として細菌叢の著しい変化が括こっ た. 好気性菌数は回腸末端部より肛門側では，ほぼ $10^{8} / \mathrm{g}$ に一定していたが，嫌気性菌数は肛門側に行くにしたが って増加していった．健康人の翼便 $1 \mathrm{~g}$ 中には $10^{10 \sim 11}$ 個 の細菌が存在し，嫌気性菌が優勢で，好気性菌数は嫌気 性菌数の約 $1 / 100$ であった

\section{2. 大腸手術前渴管処置法}

このように，消化管内には多種多数の腸内細菌が常在 しており，消化器外科手術では，腸管内細菌の污染によ り創感染, 腹膜炎, 膿汮形成等の術後感染が発生する. とくに，常在細菌が多く，嫌気性菌優勢の大腸手術で
は, 術後感染症が高率に発生し, 術後感染巣より嫌気性 菌户 E. coli, Klebsiella Enterococcus 等の腸内常在細菌 が高頻度に分離される. 大腸手術の術前腸管処置法と して，腸管内細菌鋠を减少させる目的で，経口的に抗生

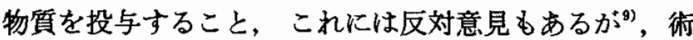
後の感染症の発生を予防できるといら利益の方が大きい ため ${ }^{10) 112)}$ ，今日広く行われている.

そこで，大腸手術に扑ける術前腸管処置法による腸内 細菌叢の変化を，抗生剤無投与群（機械的洗浄の及）, $\mathrm{KM} 1$ 剂投与群，KM+CLDM 投与群，KM+MET 投 与群, $\mathrm{KM}+$ Erythromycin (EM) 投与群の 5 群に分け て細菌学的に検討した．機械的洗浄のみでは腸内容の清 浄化は期待できるが，腸内常在菌の減少を期待すること はむずかしく，また，KM 1 剤では好気性菌は減少し ても，嫌気性菌が減少せず，総細菌数では变化が認め られなかった. KM+CLDM または MET，または EM の抗生剤 2 剂投与群では，好気性・嫌気性両菌の減少を 期待することができ，腸内常在菌の减少の面からは抗生 剂 2 剂投与法が 有効であった（図3)。機械的洗浄の徹

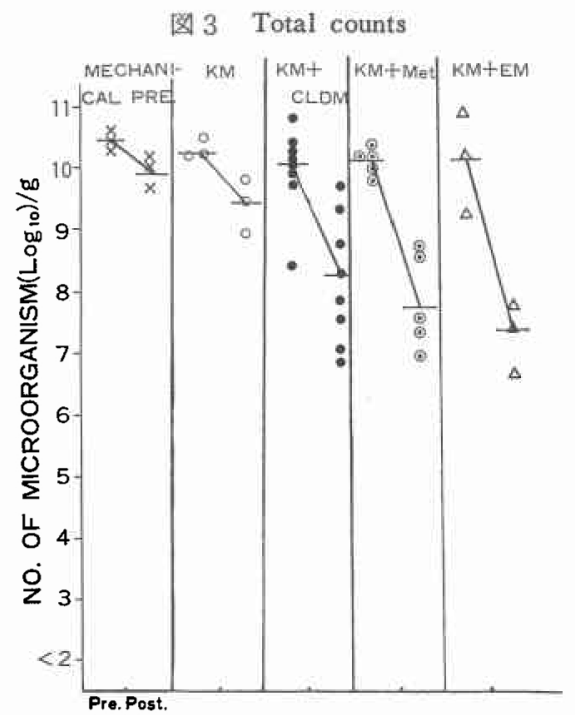

底化は腸内殺菌法の必要条件ではあるが，これだけでは 抗生刘投与の代用とはならず，腸内常在細菌の減少はみ られなかった，私どもの教室では，表6のようなスケジ ニールで大腸手術前腸管処置を行っている。

\section{3. 大腸手術における術中腸管洗浄法}

私どもの教室では，最近，潰愓性大腸炎や大腸ポリポー ジスに対して, 全結腸切除・直腸粘膜切除・回腸肛門吻 
表 6 大腸手術前の腸管処置

\begin{tabular}{|c|c|c|}
\hline $\begin{array}{l}\text { 入院当日 } \\
\text { 術前3日 }\end{array}$ & より低残 & 查食，ED，IVH \\
\hline P.M. & $2^{\circ}$ & ヒマシ油 $30 \mathrm{ml}$ \\
\hline 術前2 日 & & \\
\hline P.M. & $1^{\circ}$ & $\begin{array}{l}\mathrm{KM} 1.5 \mathrm{~g}+\text { Metronidazole } 500 \mathrm{mg} \\
\text { (又はCLDM } 300 \mathrm{mg} \text { ) }\end{array}$ \\
\hline P. M. & $10^{\circ}$ & $\mathrm{KM} 1.5 \mathrm{~g}+$ Metronidarole $500 \mathrm{mg}$ \\
\hline 術前 1 日 & & \\
\hline A. M. & $8^{\circ}$ & 流動 食 \\
\hline & $10^{\circ}$ & マグコロン1本 \\
\hline & $12^{\circ}$ & 流 動 食 \\
\hline P.M. & $1^{\circ}$ & $\mathrm{KM} 1 \mathrm{~g}+$ Metronidazole $250 \mathrm{mg}$ \\
\hline & $2^{\circ}$ & $\begin{array}{l}\text { （又はCLDM 150mg） } \\
\text { 同上 }\end{array}$ \\
\hline & $3^{\circ}$ & ソルダナ 2 錠, 水 $200 \mathrm{ml}$ \\
\hline & $5^{\circ}$ & 流動 食 \\
\hline & $8^{\circ}$ & 食熆浣腸 $500 \mathrm{ml}$ \\
\hline & 就寝前 & ソルダナ 2 嵞, 水 $200 \mathrm{ml}$ \\
\hline & $11^{\circ}$ & $\mathrm{KM} 1 \mathrm{~g}+$ Metronidazole $500 \mathrm{mg}$ \\
\hline & & （又はCLDM $300 \mathrm{mg}$ ) \\
\hline 手術当日 & & \\
\hline A. M. & $7^{\circ}$ & グリセリン浣腸 $100 \mathrm{ml}$ \\
\hline & $9^{\circ}$ & 手術 \\
\hline （輸液は: & 䇛例によ & り適宜) \\
\hline
\end{tabular}

合術を積極的に行っているが ${ }^{13)}{ }^{14)}$ ，この術式の成績を 左右するのは，直腸筋筒と回腸間の膿瘍形成 (cuff abscess）であり，これを予防することが本術式を成功させ るのに最も重要である，そのためには，今までの抗生剤 2 剂投与以上にさらに厳格な腸内殺菌法, すなわち，腸 内を無菌に近い状態にすることが要求される.そこで, 私どもは抗生剂 2 剂投与による大腸手術前腸管処置法に
加えて, 術中腸管洗浄法を採用して好成績を得ている. 手術直前に32号フォーリーカテーテルを肛門に挿入，ハ ルーンを膨ませて， $0.02 \%$ ヒビテングルコネート 1,000 $\mathrm{ml}$ で洗浄, 次いで $0.1 \%$ セフロチン水 $1,000 \mathrm{ml}$ で洗 浄，これを手術開始時と腸管切除直前の 2 回行ってい る.この効果を細菌学的に検討すると，好気性菌数は術 前腸管処置法よりもさらに減少し，12例中 6 例において 検出されず，嫌気性菌む12例中 9 例において検出されな かった. 総菌数においても5 例 $(41 \%)$ に細菌は検出され ず，腸内をほぼ無菌に近い状態にすることが可能であっ た（図 4 ）. 最近では，大腸手術に広く応用しているが， 術中腸管洗浄による副作用，合併症は認めていない。

\section{4. 大腸手術における術後感染予防の効果}

教室に拉ける過去10年間の大腸切除・吻合術を行った 症例の術前腸管処置法別の創感染発生頻度は，抗生剂無 投与群では $33.6 \%$ ，抗生剂 1 剂投与群では33.3\%である が，抗生放 2 剂投与十術中腸管洗浄群では $9.5 \%$ と低下 している。術後感染症全体をみても，年次別発生頻度 は，抗生剤 2 剂投与前30〜 40\%であったのが，2 剂投与 後には20\%台に，術中腸管净浄法を取り入れるようにな った最近 $2 \sim 3$ 年間では $12 \sim 13 \%$ と低下し, 大腸手術に 対する術後感染予防対策が役立ったものと考穴ている.

しかし，大腸手術後感染症の発生頻度の低下には，こ れらの腸管処置法による腸内常在細菌の 減少だけでな く, 表 7に示す如く, 術中には手術野の污染に対して細 心の注意を払い，外因性および内因性細菌による污染を 防止し，閉腹前の腹腔内洗浄の徹底化，吸収糸，乇/ 1ラメント糸などの異物反応の少ない縫合糸の使用, 閉
TOTAL AEROBES

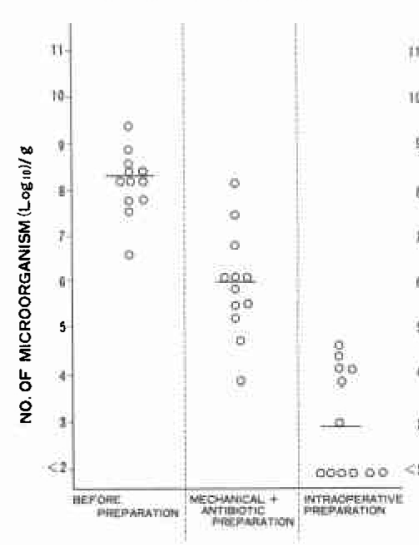

TOTAL ANAEROBES

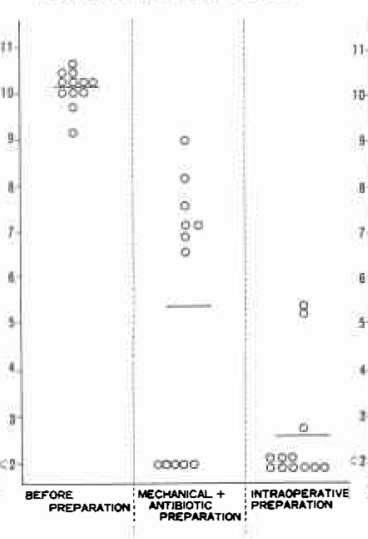

TOTAL COUNTS

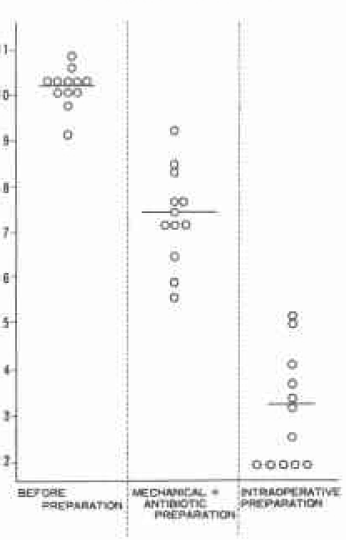


表 7 術後感染症の要因と予防対策

\begin{tabular}{|c|c|}
\hline $\begin{array}{l}\text { 細 菌 } \\
\text { 内因性 }\end{array}$ & \\
\hline 腸内細菌 & 術前の腸管処置 \\
\hline 腸管内- - - - & 術中の腸管洗浄 \\
\hline 腸管外- - - - & 腸腔内洗浄 \\
\hline & $\begin{array}{l}\text { 抗生物質投与（全身性，局 } \\
\text { 所性） }\end{array}$ \\
\hline 皮庙常在紐菌.. & 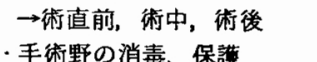 \\
\hline 外团性 …… & $\begin{array}{l}\text { 手術器械, ゴム手，マクス } \\
\text { およむ゙空中落下細菌対策等 }\end{array}$ \\
\hline 異物・手術手技 & \\
\hline $\begin{array}{l}\text { 繾合材料-・・- } \\
\text { 疑血・その他の微小 }\end{array}$ & $\begin{array}{l}\text { - PGA, monofilament 等 } \\
\text { - 洗浄 (腹腔内, 創) }\end{array}$ \\
\hline & 閉鎖性持続吸引ドレナージ \\
\hline 宿 主 & \\
\hline 感染抵抗性減弱 - - & - 全身状態の改善 \\
\hline (全身的 - 局所的) & 各種基礎笑患の改善 \\
\hline & 免度補充, 補強療法 \\
\hline
\end{tabular}

鎖性持続吸引ドレナージの採用，術前・術中・術後の予 防的抗生剤投与等の術後感染予防対策が効を奏したもの と思われる。

\section{IV おわりに}

消化器外科手術飞括讨る術後感染症の大部分のも は, 消化管内の常在細菌が術中に手術野に散布されるこ とにより発生する。術後感染の予防のためには, 術前・ 術中・術後にわたる対策が，必要である．とくに，大腸 内には，他藏器と比較して，多種多数の好気性菌とそれ を上回る嫌気性菌が常在し, 腸内容 $1 \mathrm{~g}$ 中には $10^{10 \sim 11}$ 個 の細菌が存在する ${ }^{15)}$ 。この上らな事実が，大腸手術後に 創感染症を中心とした術後感染症の多発生の原因であ り, 感染起炎菌としては, 腸内細菌属や嫌気性菌が高頻 度に検出される理由でもある.大腸手術に際しては，他 臓器手術時よりるさらに厳格な感染予防対策が術前より 要求される.また，消化管各部位の常在細菌叢の実態を 十分に理解し, 消化器外科領域における最近の術後感染 起炎菌の検出状況, 感受性傾向, 臓器別の特徵を把握す ることが術後感染の予防対策と治療においては重要であ る. 敋なわ，抗生物質の予防的投与队感染症の治療開 始時においては，起炎菌の種類およびそれらの薬剤感受 性傾向を推定して薬剂選択をすることが大切であり，盲 目的に抗生物質投与を長期間，たた慢然と行うことは, 副作用扰よび而性菌の出現, opportunistic infection の 問題から慎しむべきことである.

術後感染の予防・治療にあたっては，紐菌による污染
防止，異物除去，手術手技，化学療法剂の投与などの対 策も重要であるが，個体の持っている感染に対する防禦 機能が感染症の予防，治療効果を大きく左右することを 念頭に怙いて, 術前術後の患者管理においては, 全身状 態・栄養状態の改善や, 重篤な基礎疾患の治療を行い, 積極的に個体の感染防禦能を高める努力をすることが最 も重要である。

\section{文献}

1) 光岡知足：腸内細菌叢とその意義. 臨床と細 菌, 2 : 197-239, 1975.

2）中谷林太郎：ヒトの正常晹内細菌鋠とその意 義. 新薬と治暆, $7: 10-12,1974$.

3) Joseph W. Holland, et al.: Numbers and types of anaerobic bacteria isolated from clinical specimens since 1960 . J. Clin. Microbiol., 5: 20-25, 1977.

4）石山俊次汪か：嫌気性菌感染症。外科治療, 34: 505-512, 1976.

5) 光岡知足：腸内紐菌丵の検查手技. 感染症学会 雑誌, 45：406-419, 1971.

6) 今村博務：Clindamycin に対する Bacteroides flagilis の耐性獲得比関する研究。第 1 報, chemotherapy, 25 (2) : 380, 1977.

7) 螺良英郎ほか：Opportunistic infection, 最新医 学, 34: 1417-1422, 1979.

8）井上敏直 : 大腸手術後の各種人工肛門拈よび吻 合術における腸内細菌鋠の変化. 日消外会誌, $13: 23-34,1980$.

9) Vink, M.: Local recurrence of cancer in the large bowel; the role of implantation metastases and bowel disinfection. Brit. J. Surg., 41: 431-433, 1954.

10) Nichols, R.L., et al.: Effect of preoperative neomycin-erythromycin intestinal preparation on the incidence of infections complication following colon surgery. Ann. Surg., 178: 453462, 1973.

11) Pollock, A.V., et al.: The role of antibacterial preparation of the intestine in the reduction of primary wound sepsis after operations on the colon and rectum. Surg. Gynecol. Obstet., 147: 909-912, 1978.

12) James, S.C., et al.: Preoperative oral antibiotics reduce septic complications of colon operations. Ann. Surg., 186: 251-259, 1977.

13）宇都富譲二汪か：全結腸切除・直晹粘膜切除・ 回腸肛門吻合術一序説一. 外科訩療, 21 : 268一 $280,1979$.

14）宇都宮譲二ほか：全結腸切除・直晹粘膜切除 回腸肛門吻合術術式の開発. 手術, 33: 741$749,1979$.

15) Moore, W.E.C., et al.: Human Fecal Flora. The normal flora of 20 Japanese-Hawaians. Appl. Microbiol., 27: 961-979, 1974. 